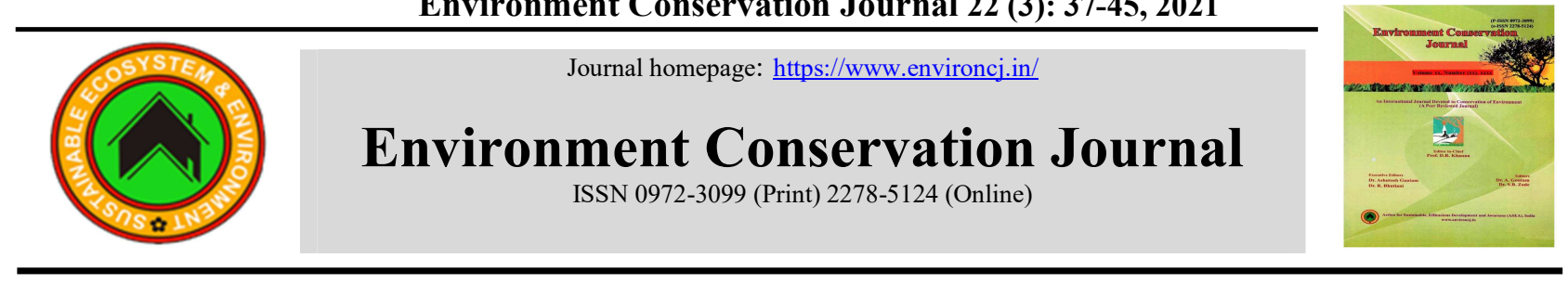

\title{
Stubble burning: Root cause, impacts and its management in Indian scenario
}

\author{
Rohith Gottipati 网 \\ Department of Agronomy, Lovely Professional University, Punjab \\ Burra RaghavendraM N Pavan \\ Department of Agronomy, Lovely Professional University, Punjab \\ Sandeep Menon \\ Department of Agronomy, Lovely Professional University, Punjab
}

\begin{tabular}{|c|c|}
\hline ARTICLE INFO & ABSTRACT \\
\hline $\begin{array}{l}\text { Received : } 27 \text { April } 2021 \\
\text { Revised : } 22 \text { June } 2021 \\
\text { Accepted : 06 July } 2021 \\
\text { Available online: } 19 \text { November } 2021 \\
\text { Key Words: } \\
\text { Greenhouse gases } \\
\text { Happy seeder } \\
\text { In-situ management } \\
\text { Stubble burning } \\
\text { Stubble management }\end{array}$ & $\begin{array}{l}\text { The practice of purposefully setting fire to the residue that remained after } \\
\text { harvest of rice and wheat crop is increasing periodically. Stubble burning has } \\
\text { become one of the challenging issues in India in recent times. Government has } \\
\text { been consistently instructing farmers not to burn the crop residues, instead } \\
\text { asking them for in-situ management. Farmers are citing various complications } \\
\text { in stubble management which pulling them to setting up fire to the stubble. } \\
\text { Rice straw burning generates life threatening greenhouse gases which causes } \\
\text { air pollution injury. Particulate matter (PM2.5) levels in the capital state of } \\
\text { India (New Delhi) have been exceeded by } 14 \text { times than threshold level because } \\
\text { of episodic agricultural fires in the neighbouring states namely Punjab, } \\
\text { Haryana. A very limited study has been done so far on this complete issue } \\
\text { despite of its importance. The present review tried to expose root cause, impacts } \\
\text { on ecosystem and management strategies of stubble burning especially in India. } \\
\text { There are plethora of possibilities in managing residue in sustainable ways } \\
\text { including in-situ residue management, mushroom production, livestock feed, } \\
\text { composting, biochar preparation, bio-thermal power plants and paper } \\
\text { industries. Mechanical and effective method of in-situ management has been } \\
\text { come into existence in the form of happy seeder. Depending on the land holding } \\
\text { farmers can follow any of the said methods and manage their residue in } \\
\text { sustainable way by overcoming the constraints thereby reducing the impacts on } \\
\text { ecosystem. }\end{array}$ \\
\hline
\end{tabular}

\section{Introduction}

Stubble or residue is the left over/remaining material after the harvest of crop. In other words all the plant parts other than economically important material is known as residue. Around the globe, among all the crops most of the residue accounts from cereals and pulses. Considering in India, rice and wheat stands way front when we compare with other cereals and pulses. Both rice and wheat together contribute about $30 \%$ of global food needs by making it major source of food for billions of people around the world. India stands second in rice and wheat production after China, by producing 175.58 Mt of rice and 101.29 Mt of wheat per annum. Moreover, approximately rice covers an area about 44 million ha and wheat covers 29.5 million ha, which resembles the importance of both the crops in Indian agriculture. According to the Indian Agricultural Research Institute (IARI) in New Delhi, cereal crops produce the most residues, with 352 Mt. Paddy and wheat account for $34 \%$ and $22 \%$ of total production. Burning crop residue insitu is the easiest way to clear an agricultural field and begin land preparation for the succeeding crop. Stubble burning is deliberate act of burning the left over crop residues in the field in order to start land preparation for sowing of following crop. Ricewheat cropping pattern is prominent in India; precisely it is mostly followed in Indo-Gangetic 
plains of Haryana and Punjab which accounts largest quantity of stubble burning in India (Sain, 2020). Mostly, rice is harvested using combine harvester which leaves considerably more quantity of residue in the farm land itself. Lack of time to collect and make use of the left over material instead, farmer burn those residues so that land preparation can be started immediately to sow wheat crop in the month of November.

Furthermore, Rice straw is not preferred by animals because of elevated levels of silica. So, farmers cannot take it to their animals, which force them to burn those residues in the field itself. Rice straw contains some life threatening compounds such as methane. A large portion of the stubble produced is burned on the field. The Indian Agricultural Research Institute (IARI) reports says, about 63.6 percent i.e., 14 million tons has been set to fire every single year out of the 22 million tons of the generated rice stubble (IARI, 2012). Two of India's most important rice-producing states I.e., Punjab and Haryana, account for nearly half of the total stubble burned (Gadde et al., 2009).

\section{Root cause for stubble burning in India}

After Green Revolution in India (1960s), various changes in Indian agriculture system both in acts by government and pattern of farming by farmers has been noticed. Since then, raise in food production every year, particularly in rice and wheat is recorded in order to feed the booming population of the country. As there is growth in crop production there is increased biomass production as well which leads to mass residue remains on the land after harvesting of crop. Every single year, Leaves, stubble, straw, stems, and other field residues produce a huge amount of waste. Paddy produces the most cereal crop residues, accounting for $53 \%$, and $33 \%$ from wheat. Crop residue generated was $253 \mathrm{Mt}$ in 2010. Various research studies showed different statistics of crop residue generation (Table $1)$. It is quite challenging for farmers to manage substantial amount of stubble, which drags them to setting fire (Sain, 2020). Following are the most probable reasons of stubble burning in India:

- Lack of time period between two successive crops: As far as agriculture is concerned, Fundamental and most important agronomical practice is 'time/date of sowing'. Recommended time of sowing Paddy is second fortnight of May and transplanting is second fortnight of June to maximum of 5th July and crop reaches its maturity in the month of November. Ironically, time of sowing for succeeding wheat crop in rice-wheat cropping pattern is first fortnight of November leaving no time period for farmers in proper management of rice straw. Nevertheless, late sown varieties has come into existence, it can go upto first week of December leaving maximum of 20 days between two successive crops (Ravindra et al., 2018).

Table 1: Crop residue generation in India.

\begin{tabular}{|l|l|}
\hline \multicolumn{1}{|c|}{ Author and year } & $\begin{array}{l}\text { Crop residue } \\
\text { generated in india }\end{array}$ \\
\hline Mandal et al. (2004) & $350 \times 10^{\wedge} 6 \mathrm{~kg}$ year \\
\hline Gupta et al. (2004) & 347 million tonnes \\
\hline Garg (2008) & $133,138 \mathrm{Gg}$ \\
\hline Agarwal et al. (2008) & $184,902 \mathrm{Gg}$ \\
\hline $\begin{array}{l}\text { Government of India } \\
\text { (2016) }\end{array}$ & 500 million tonnes \\
\hline IARI (2012) & 352 Million tonnes \\
\hline
\end{tabular}

- Lack of knowledge in stubble management: Despite the fact that farmers are unaware of residue management in short period, and they consider burning is the easiest method to get rid of crop remains, government of India is making effort to reach out and educate them (Vadrevu et al., 2019)

- Mechanical harvesters: Rice being most important cereal crop and produced in large areas, usage of man power for harvesting is extravagant. Consequently, mechanical harvesters came into existence in which combine harvester is prominently used. This leaves significant amount of straw in the field itself since it is not designed to cut the plant to surface and incorporate in to soil (Mittal et al., 2009; Pratika and Sandhu, 2020).

- Lack of responsibility: Despite having knowledge on residue management and its impact on environment, few people desperately burn stubbles in the field due to which new rules/laws has set up by lawmakers to control 
these irresponsible acts by few farmers (Parmod et al., 2015).

- Unlikely for cattle: Most of the cereal and forage crops residue is used in dairy as feed for cattle. Despite the fact that rice straw is not preferred in Northern regions as cattle feed due to increased silica, ligno-cellulose and limited protein content $(2-7 \%)$ which leaves no option of taking rice straw to the dairy. However, basmati rice fodder is somehow preferred by cattle because of its high palatability ( $\mathrm{Na}$ et al., 2014).

- Scarcity of labour and Escaping from labour cost: Due to increase in intensive agriculture, a steady decrease in usage of man power has been noticed over years and increase in mechanical power is seen due to which the contribution of agricultural workers and overall workers has been plummeted from $62.67 \%$ to $35.96 \%$ since1970-71 to 2012-13 in Punjab. Wages for labour has been sky-rocketed these days. In order to reduce these expenses, farmers simply burn their residue which not even costs a penny (Parmod et al., 2015) (Figure 1).

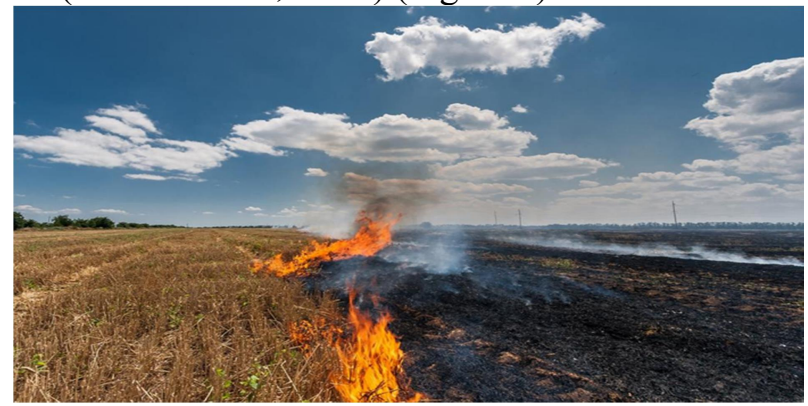

Figure 1: In-situ Stubble burning.

Source:

https://www.downtoearth.org.in/blog/agriculture/stu bble-burning-a-problem-for-the-environmentagriculture-and-humans-64912

\section{Impacts of stubble burning}

Deliberate act of firing stubbles not only creates damage to environment it also causes serious damage to human, wildlife and soil.

- Effect on Environment: Burning crop residues can produce greenhouse gases as well as other chemically and radioactively significant trace gases and aerosols including methane, carbon monoxide, nitrous oxide and other hydrocarbons. As a result of burning rice straw it is estimated that, Carbon $(\mathrm{C})$ is emitted as $\mathrm{CO} 2$ $(70 \%), \mathrm{CO}(7 \%)$ and $0.66 \% \mathrm{CH} 4$ where as $2.09 \%$ of Nitrogen $(\mathrm{N})$ in straw is emitted as $\mathrm{N} 2 \mathrm{O}$. Moreover, burning of agriculture waste also produces large amount of particulate matter that is contains a wide variety of organic and inorganic organisms. The majority of the contaminants present in large amounts in biomass smoke are confirmed or suspected carcinogens that can cause a variety of lung diseases when inhaled. Despite various air quality improvements taken place during 2019 and 2020, air pollution in India is still desperately high. Unfortunately, India continues to maintain annual PM2.5 rankings by city. Globally, 22 Indian cities of the top 30 most polluted cities are located in India. In the northwest part of India, residue burning contributes only about $20 \%$ of organic and elemental carbon to the total national budget of pollution from agricultural waste burning. $\mathrm{CO}_{2}$, $\mathrm{CO}, \mathrm{N}_{2} \mathrm{O}$, and $\mathrm{NO}_{\mathrm{X}}$ emissions from rice and wheat straw burning were found to be approximately $2.306,0.11,0.002$, and 0.084 million tonnes, respectively, by Gupta et al. (2016). Burning of crop residue releases 4.1, 91, $0.6,0.1$, and 1.2 tera grams per year of $\mathrm{CO}, \mathrm{CO}_{2}$, $\mathrm{CH}_{4}, \mathrm{NOx}$, and total PM respectively (Yevich and Logan (2003)). 100 percent of carbon, 8090 percent of nitrogen, 25 percent of phosphorus, 20 percent of potassium, and 50 percent of sulphur found in various crop remains are released as harmful gases and particulates (PM) that pollute the air. Burning rice straw and stubble results in massive soil nutrient losses, including organic carbon of $3.85 \mathrm{MMT}$, nitrogen of 59,000t, phosphorus of 20,000t, and potassium of $34,000 \mathrm{t}$ as well as a significant reduction in ambient air quality, as per official requirements. According to a study conducted by the National Remote Sensing Agency in Punjab ( May 2005), on burning wheat crop residue, about $113 \mathrm{Gg}$ of $\mathrm{CO}, 1.33 \mathrm{Gg}$ of $\mathrm{CH}_{4}$, $8.6 \mathrm{Gg}$ of $\mathrm{NO}_{2}, 12 \mathrm{Gg}$ of PM2.5 and $13 \mathrm{Gg}$ of PM10 and paddy straw burning was predicted to contribute $261 \mathrm{Gg}$ of $\mathrm{CO}, 3 \mathrm{Gg}$ of CH $4,19.8 \mathrm{Gg}$ of NO2, 28.3 Gg of PM2.5 and $30 \mathrm{Gg}$ of PM10 The air quality index, or AQI, is a range of categorical measure of pollution levels that help 
explain the quality of air in a given area on a scale of 0-500. (Central Pollution Control Board, 2014) (Figure 2). The majority of Northern India's regions have exceeded the AQI threshold, which is hazardous to the atmosphere, especially during the peak burning months. For instance, in November 2019, Delhi's peak AQI was 487,
Greater Noida's was 480, and Ghaziabad's was 493. These AQI levels are specifically in the "Hazardous" category, as per the CPCB AQI (figure 2). This compelled the government of New Delhi and a few other northern states to close primary schools and alert people about early morning outdoor activities (Kapil, 2019).
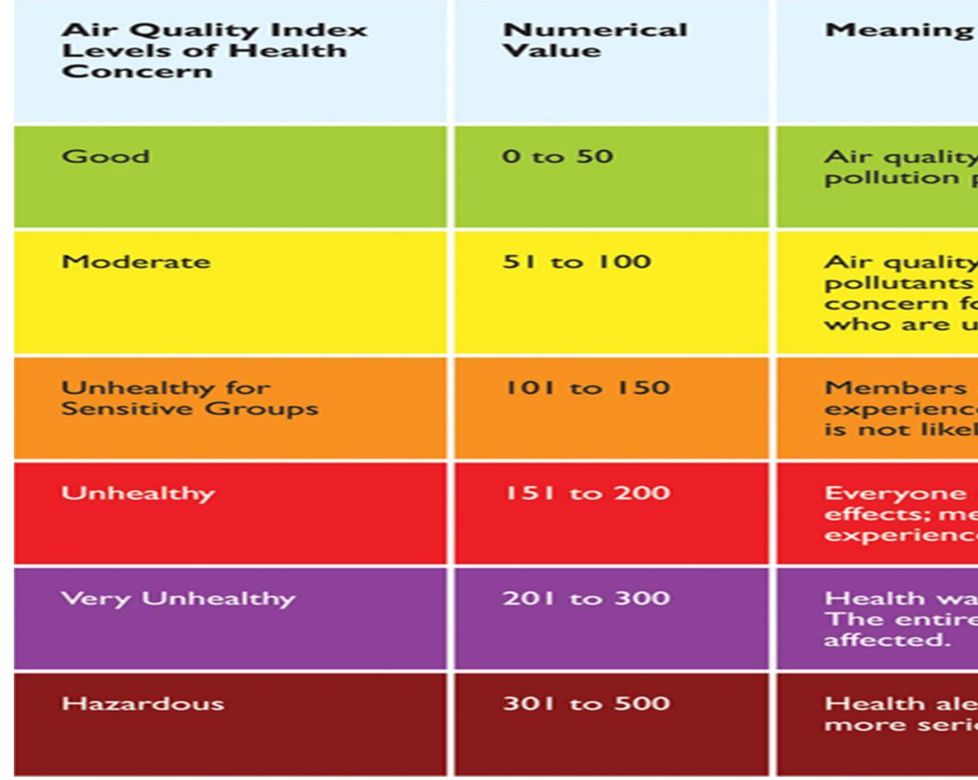

Air quality is considered satisfactory, and air pollution poses little or no risk.

Air quality is acceptable; however, for some pollutants there may be a moderate health concern for a very small number of people who are unusually sensitive to air pollution.

Members of sensitive groups may experience health effects. The general public is not likely to be affected.

Everyone may begin to experience health effects; members of sensitive groups may

Health warnings of emergency conditions. The entire population is more likely to be affected.

\section{Health alert: everyone may experience}

Figure 2 : Air quality index levels (Source: AirNow. http://airnow.gov/index.cfm?action=pubs.aqguidepart)

- Effect on human health: The impact of stubble burning on the atmosphere is directly proportional to the impact on human wellbeing. This is because all the heavy metals or lethal gases released as a result of residue burning not only damage the ozone or cause environmental pollution but also act as slow poison in human body. Several studies have identified a link between air pollution and the risk of a variety of health problems, including pregnant women, infants, the elderly, and people with a history of health problems. Wide range of respiratory, cardiovascular, neurological, skin and optical diseases has been noticed due to the exposure of human to these life-threatening gases. In few cases, people with pre-existing respiratory disorders may even decease (Saggu et al., 2018). On exposure to smoke symptoms such as Eye irritation, eye watering, and conjunctival hyperemia are noticed. Efficiency of blood to take oxygen is reduced and respiratory problems are created due to Carbon Monoxide (a poisonous gas) which is released during paddy straw burning on reaction with red particles reduces. Likewise, Carbon dioxide emitted creates eye irritation and the oxides of Sulphur dioxide and Nitrogen directly affect lungs, skin, blood and respiratory functions which can trigger serious diseases such as cancer (Punjab Pollution Control Board, 2018). According to the Punjab Pollution Control Board's report, during paddy straw burning period about 425 milligram per cubic meter respirable fine particles is released whereas 60 milligram per cubic meter is released during normal days. Furthermore, Fine particulate matter (PM2.5) shows more effect on humans than the larger sized particles, as it has the ability to pass through the trachea, through the lungs, and then through the bloodstream, causing long-term damage. Saggu et al. (2018) found that children who were exposed to a greater degree of particulate matter had poorer respiratory and lung function. Besides these, other symptoms of 
contaminated pollution include cardiac arrest, asthma, lung cancer, and mild diseases in the respiratory tract (Saggu et al., 2018).

- Effect on soil fertility and properties: Stubble burning in the farm itself results in extreme damage to soil properties. According to Gupta (2008), crop stubble blazing increases the soil temperature by up to $33.8-42.2^{\circ} \mathrm{C}$. Burning of crop residue in-situ also results in the depletion of 27-73 percent of nitrogen in the soil and deteriorates the microbial population i.e., bacteria, fungi on the upper layer of soil I.e., 2.5 $\mathrm{cm}$ which is most fertile layer. Furthermore, periodic burning will reduce the beneficial soil bacterial population by up to $50 \%$. It also decreases total nitrogen, carbon, and available nitrogen in the top $0-15 \mathrm{~cm}$ soil layer, along with soil organic matter reduction. Mandal et al. (2004), blazing of wheat and rice stubble results in the depletion of most important nutrients in notable numbers (Table 2) from the soil. It also causes the loss of essential nutrients found in field stubble. Plant residues carry about $25 \%$ of the nitrogen and phosphorus uptake, $75 \%$ of the potassium, and $50 \%$ of the sulphur uptake by cereal crops, making them suitable nutrient supplies for following crops (Gadde et al., 2009). Singh et al. (2008) reported, nutrient depletion due to rice residue burning in Punjab in 2001-2002 was $35 \mathrm{~kg}$ nitrogen, $3.2 \mathrm{~kg}$

Table 2 : Loss of soil nutrients due to stubble burning (Source: Mandal et al., 2004)

\begin{tabular}{|c|c|c|}
\hline SN & Nutrient & $\begin{array}{c}\text { \% Lost due to burning } \\
\text { from soil }\end{array}$ \\
\hline 1 & Nitrogen (N) & 80 \\
\hline 2 & Phosphorus (P) & 25 \\
\hline 3 & Potassium (K) & 21 \\
\hline 4 & Sulphur (S) & $4-60$ \\
\hline
\end{tabular}

phosphorus, $21 \mathrm{~kg}$ potassium, $2.7 \mathrm{~kg}$ sulphur, and $2400 \mathrm{~kg}$ carbon per hectare. Carbon and nitrogen losses were nearly complete, while phosphorus, potassium, and sulphur losses were minimal (around 20-60 percent).

\section{Management of crop residue}

Crop residue can be utilised in various ways which requires some basic knowledge and general awareness.

- Crop residue as fodder for animals: Crop residues come in first place when we talk about animal feed in India. Wheat and maize straw are used as primary source of animal feed in Northern India. On the contrary, rice straw comes in first place in southern part of country nevertheless of its high silica content maybe because of unavailability of other sources of feed. Rice husk is made into fine powder and fed to animals particularly, cattle in southern India. Mixing urea with dry straw and used as feed for livestock enhances their health condition. Statistics of crop residues requirement and availability for livestock in India shows that there is a requirement of 415.83 million tons whereas 253.26 million tons of crop residue is only available. Therefore, approximately $40 \%$ shortage in livestock feed in the form of crop residue is recorded. However, green fodder demand during same time span is 221.63 MT whereas availability is 142.82 MT with nearly 36 $\%$ shortfall (Parmod et al., 2015).

- Crop residue as bedding material for cattle: Paddy straw is used as bedding material in cattle shed which is commonly done in southern states of India. However, now a days this is also practiced in northern parts mostly during cold seasons on government recommendation. Results from the study conducted at college of agriculture, PAU showed a significant improvement in quality and quantity of milk production because of the comfort, leg and udder health provided by crop residue bedding during winter months. Bedding in winter seasons helped cattle in keeping warm and regulates the body's heat loss. Moreover, It creates a safe, hygienic, secure, dry, and gripping atmosphere, reducing the likelihood of lameness and injury. Healthy legs and hooves contribute to increased milk production and reproductive ability in livestock (Mandeep et al., 2012). This used paddy straw can later be reused in biogas plants.

- Crop residue in Biogas plants: Fossil fuels can be replaced by biogas as an alternative, which is produced from agricultural wastes. Agricultural 
crop residues particularly, rice straw is a major source of lignocellulose which is required in the production of biogas. Biogas and bio char can also be produced from the agriculture residues. Grinders are used in production of biogas in order to chop the stubbles into little chunks and placing them in digesters with other materials. This is completely anaerobic process by which it not only produces biogas but also solid and liquid organic fertilizers as by-products (Ravindra et al., 2018; Singh et al., 2016).

- Crop residue in Bio thermal plants: Residues of paddy play a major role in Electricity generation in bio thermal plants. These days many institutions and power plants are encouraging usage of rice residue to generate Electricity by which farmer can overcome stubble burning and gain some profit for their residue. Agricultural residue can also be used to produce energy through extraction, methanation, or gasification. Farmers can sell crop residue to power plant industries for 350 rupees per tonne (Kumar et al., 2015). The energy potential of agricultural stubble produced in India is approximately 1570 petajoules per year. Moreover, The Ministry of New and Renewable Energy (MNRE) and the Central government have built nearly 500 power plants in the country that are either partly or entirely powered by biomass. These power plants, with a combined installed capacity of $8,700.8 \mathrm{MW}$, contribute approximately 11.5 percent of the overall renewable power produced in the country.

- Crop residue in Mushroom Production: Residues of rice, wheat and sugarcane bagasse are excellent sources of substrate in mushroom production. Paddy straw is comparatively cheaper source with high lignocellulosic content which is highly preferred for mushroom making. Hence, it can be profitably utilized in mushroom production to combat the booming cost of mushroom production. Among various mushroom species, Agaricus bisporus (button mushroom), Calocybe indica (milky mushroom), Volvariella spp. (paddy straw mushroom), and oyster mushroom (Pleurotus ostreatus) are most commonly available edible species in India. The growth of these mushrooms largely depends upon the type of compost used for their nutrition. However,
Efficiency of the mushroom spawn to make use various components of compost depends upon the substrate used in bagging which further depends on many physiochemical factors responsible during the composting process and mushroom growth. Despite having huge scope to utilise crop residue only $0.03 \%$ of field crop residues are used in mushroom production in India (Gupta et al., 2016).

- Crop residue in compost making: Composting is the traditional method of preparation of enriched organic material. Composting is a natural mechanism that involves the breakdown of organic materials such as animal waste, crop residues, vegetable waste, and some municipal waste with the involvement of some microorganisms. It is used as natural organic fertiliser upon completion of the decomposition process. This natural fertilizer improves the soil physical, chemical, and biological properties. The harvest refuses include stubble, straw, stover and haulms of various crops. Crop remains from thrashing sheds and left over material during crop processing are also used in composting. These residues have tremendous potential to be used as organic fertiliser after it turns to manure by process of composting. Furthermore, One kilo gramme of straw absorbs about $2-3 \mathrm{~kg}$ of urine from an animal shed. One hectare of paddy straw yields almost 3.2 tonnes of nutrient-rich manure as FYM. This residue can be prepared by farmer in their shed and reused as organic fertiliser and it has the potential to increase crop yield by 4-9 percent.

- Crop residue in paper industries: The paddy straw along with wheat straw in the ratio of 40:60 is used in papermaking. The sludge from the remains after paper making could be used to produce energy by bio-methanization. This technology is already in use in some paper mills, where it provides approximately 60 percent of the energy needed. Paddy straw is also used as a common raw material in the production of paper and pulp board (Sain, 2020). This management practice might somehow possibly be an alternative to deforestation.

- In-situ crop residue management: Managing the stubble in the farm itself is one of the best management practices done by farmers 
since it will have advantages out of very less cost. Effective utilisation of crop residue in-situ is by two methods I.e., stubble incorporation and stubble mulching. Stubble incorporation: In this method, straw is incorporated into the soil after harvesting either manually or by heavy machines like rotavators, choppers etc., which cut the straw and incorporate into soil. Rice straw can be managed in the agriculture land itself successfully by allowing 20-25 days, which is sufficient between incorporation of straw and seeding of wheat crop to prevent nitrogen shortage because of $\mathrm{N}$ immobilisation. Nitrogen and straw application solely or by combined use improved biomass carbon, respiratory activities and phosphates in the soil. The highest levels of microbial biomass carbon and phosphate were found 30 days after straw decomposition. Results of field experiments showed that by incorporating paddy straw 21 days prior sowing of wheat, a significant increase in wheat yield is observed in clay loam soil at Sonepat district where as no any beneficial results are seen in sandy loam soil at Hissar district.

- Stubble mulching: Stubble/straw mulching is the process of spreading of residues evenly on the land surface such that soil erosion due to wind and water is prevented, soil moisture is conserved and weed growth is suppressed. Few studies showed, Soil moisture in the deeper layers is conserved due to mulch hence, about $40 \%$ higher root length is observed when compared with no mulch treatments (Singh and Sidhu, 2014). Usage of rice straw as mulch has decreased crop water usage by 3-11 percent, increased wheat yield, and enhanced Water Use Efficiency by 25 percent in contrast to nonmulched crop.

- Happy seeder: It is a zero till tractor-mounted mechanical implement, which cuts the erect rice straw on the land and sow the wheat seeds then makes the residue as mulch. (Figure 3) This mulch helps in conserving soil moisture, preventing soil erosion and suppressing weed growth. Moreover, usage of the happy seeder also reduces labour requirements for residue collection and sowing by $80 \%$, herbicide use upto $50 \%$ and irrigation needs upto $20-25 \%$.
Happy seeder on associating with basic straw spreading mechanism works efficiently which is called as 'Super straw management system'. This is connected to a combine harvester such that residue is distributed uniformly around the harvest width, and this super straw management method improves work quality and yield stability (Lohan et al., 2018; NAAS, 2017). Group of engineers and researchers of CSIRO Griffith and Punjab Agricultural University (PAU) first developed the Happy seeder originally in July 2001, (Humphreys et al., 2006; Sidhu et al., 2008). Currently, Around 11,000 happy seeders are being used in northern India in which about $80 \%$ are working in the state of Punjab itself (personal communication with machine manufacturers).

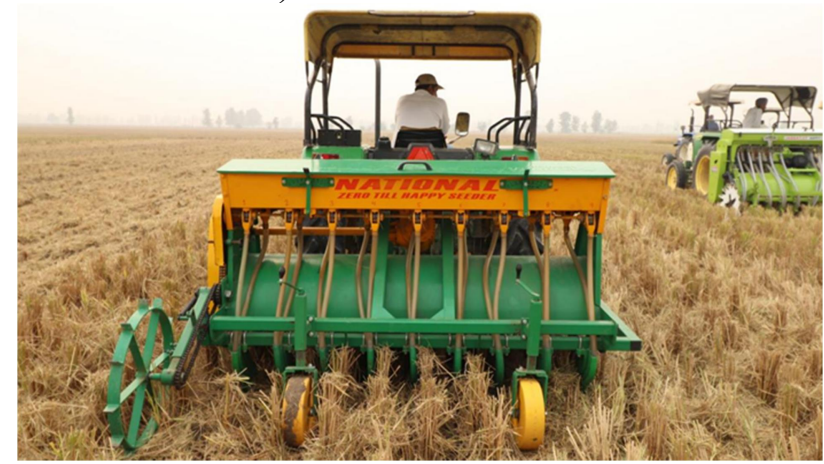

Figure 3: Working Happy Seeder. Photo Credit: Natalya Skiba at TNC

\section{- Other management practices:}

Biochar: It is similar to charcoal, which is formed by combustion organic materials such as rice straw with no or very low levels of oxygen. Biochar has been shown to increase soil fertility but not as energy source (Lehmann and Joseph, 2009). Crop residue such as rice straw can be used in packing and transportation of fruits, vegetables and glassware. It can also be used in brick making industries.

\section{Conclusion}

Considering the fact that stubble burning is most debated topic in recent times because of its hazardous effects on environment and human life. Various reasons for residue burning have been identified by farmers, researchers and government authorities. Ironically, few reasons from farmers were preposterous, for instance, escaping from 
work in collecting the straw, instead setting up fire which is solely due to lack of responsibility. Insufficient time between the harvesting of the rice crop and the planting of the subsequent wheat crop is one of the major reasons for stable burning in India due to which government and agriculture universities are consistently advising farmers to sow rice crop in nurseries 10 days earlier than previously followed date of sowing. Furthermore, environmental, human and soil health are extremely damaging due to those stubble burning activities. Environmental health in the form of air pollution, human health in the form of various respiratory, optical and pulmonary diseases and soil health by killing beneficial soil microorganisms are ruined as

\section{References}

Chawala, P., \& Sandhu, H. A. S. (2020). Stubble burn area estimation and its impact on ambient air quality of Patiala \& Ludhiana district, Punjab, India. Heliyon, 6(1), e03095.

Gadde, B., Bonnet, S., Menke, C., \& Garivait, S. (2009). Air pollutant emissions from rice straw open field burning in India, Thailand and the Philippines. Environmental Pollution, 157(5), 1554-1558.

Gupta, S., Summuna, B., Gupta, M., \& Mantoo, A. (2016). Mushroom cultivation: A means of nutritional security in India. World, 3, 6-50.

Gupta, U. (2008). Valuation of urban air pollution: a case study of Kanpur City in India. Environmental and Resource Economics, 41(3), 315-326.

Humphreys, E., Blackwell, J., Sidhu H. S., Singh, M., Singh, S., Singh, M., Singh, Y., \& Anderson L., (2006). Direct drilling into stubbles with the Happy Seeder. IREC Farmers' Newsletter, Large Area No. 172: 4-7. A $<$ http://www.irec.org.au/farmer_f/pdf_172/Direct\%20drilli ng\% 20into\%20stubble.pdf>. Accessed 5 May 2007.

Kapil, S., (2019). Public health emergency declared in Delhi due to air pollution. Down to earth, https://www.downtoearth.org.in/tag/shagun-kapil-131365/ stubble-burning (Accessed 21 June 2019).

Kumar, P., Kumar, S., \& Joshi, L. (2015). Socioeconomic and environmental implications of agricultural residue burning: A case study of Punjab, India (p. 144). Springer Nature. SpringerBriefs in Environmental Science.

Lohan, S. K., Jat, H. S., Yadav, A. K., Sidhu, H. S., Jat, M. L., Choudhary, M., \& Sharma, P. C. (2018). Burning issues of paddy residue management in north-west states of India. Renewable and Sustainable Energy Reviews, 81, 693-706. the result of crop residue burning. Lawmakers interfered after solid damage has been done however; efforts are being made to control indiscriminate burning of straw by enforcing few new solid regulations. Farmers have numerous options in managing straw which includes cattle feed, mushroom production, bio-thermal plants, paper industries, bio-char preparation, mulching, soil incorporation etc. Happy seeder is one of the finest inventions which gave a major alternative to stubble burning. It is now up to the farmers in managing their crop residues in any of the above mentioned practices other than burning and prevent the world from pollution injury.

Mandal, K. G., Misra, A. K., Hati, K. M., Bandyopadhyay, K. K., Ghosh, P. K., \& Mohanty, M. (2004). Rice residuemanagement options and effects on soil properties and crop productivity. Journal of Food Agriculture and Environment, 2, 224-231.

Mandeep, S., Sharma, A. K., Grewal, R. S., \& Parmar, O. S. (2012). Evaluation of paddy straw bedding for crossbred cows in winter. Indian Journal of Animal Production and Management, 28(3/4).

Mittal, S. K., Singh, N., Agarwal, R., Awasthi, A., \& Gupta, P. K. (2009). Ambient air quality during wheat and rice crop stubble burning episodes in Patiala. Atmospheric Environment, 43(2), 238-244.

Na, Y. J., Lee, I. H., Park, S. S., \& Lee, S. R. (2014). Effects of combination of rice straw with alfalfa pellet on milk productivity and chewing activity in lactating dairy cows. Asian-Australasian journal of animal sciences, 27(7), 960 .

Ravindra, K., Singh, T., \& Mor, S. (2019). Emissions of air pollutants from primary crop residue burning in India and their mitigation strategies for cleaner emissions. Journal of cleaner production, 208, 261-273.

Saggu, G. S., Mittal, S. K., Agarwal, R., \& Beig, G. (2018). Epidemiological study on respiratory health of school children of rural sites of Malwa region (India) during postharvest stubble burning events. MAPAN, 33(3), 281-295.

Sain, M. (2020). Production of bioplastics and sustainable packaging materials from rice straw to eradicate stubble burning: A Mini-Review. Environment Conservation Journal, 21(3), 1-5.

Singh, R. P., Dhaliwal, H. S., Sidhu, H. S., Manpreet-Singh, Y. S., Blackwell, J. (2008). Economic assessment of the happy seeder for rice-wheat systems in Punjab, India. Conference 
Paper, A.A.R.E.S. 52nd Annual conference ACT. Doi: http://dx.doi.org/10.22004/ag.econ.5975.

Singh, R., Srivastava, M., \& Shukla, A. (2016). Environmental sustainability of bioethanol production from rice straw in India: a review. Renewable and Sustainable Energy Reviews, 54, 202-216.
Vadrevu Lehmann, J., Joseph, S. 2009. Biochar for environmental management: an introduction. In: Lehmann, J., Joseph, S. (Eds.), Biochar for Environmental Management. Earthscans, London.

Yevich, R., \& Logan, J. A. (2003). An assessment of biofuel use and burning of agricultural waste in the developing world. Global biogeochemical cycles, 17(4). 